\title{
Thailand's Water Security situation in the context of the world and ASEAN
}

\author{
SUCHARIT KOONTANAKULVONG ${ }^{1}$, PIAMCHAN DOUNGMANEE ${ }^{2} \&$ \\ PIYATIDA HOISUNGWAN ${ }^{1}$ \\ 1 Faculty of Engineering, Chulalongkorn University, Thailand \\ sucharit.k@chula.ac.th \\ 2 Research Center, National Institute of Development Administration, Thailand
}

\section{INTRODUCTION}

During the RIO+20 meeting, the sustainable green economy for protecting environmental health via income increase and poor eradication was discussed. The countries with a successful, sustainable green economy depend on efficient integrated water management and provision of water supply and sanitary services. The water security index was another issue proposed to monitor national socio-economic development, and took account of domestic water, urban water, economic water (including irrigation water), river health and resilience. The study proposed the Water Security definition and assessed the water security status of Thailand by using water use status and correlated with gross domestic product per capita in various countries of the world, Asia and ASEAN (Association of South East Asian Nations), which helped understanding of the competitiveness and the strength, weakness and potential of water development in Thailand compared with the rest of the world and ASEAN countries.

\section{METHODOLOGIES}

This study determined the water security status from five dimensions, i.e. WS1: basic water (renewable, supply, hygiene); WS2: sufficient water (water supply, consumption, agricultural; water), WS3: development water (irrigation area, industrial water use, water for energy, water for aquaculture); WS4: water disaster (loss from floods and drought); and WS5: water for future (population growth, urban population growth, water footprint). The index status was analysed and correlated with water use unit (cubic metre per capita) and water productivity (US \$ per cubic metre of water use) and grouped into four groups of country classified by income per capita of the country. Based on the available data from various sources worldwide (Black and King 2009, World Bank 2014), the index of each country was determined comparatively by weighting equally from each dimensions and ranked by the marking equally (1-5 points) of each element from the average and standard deviation values.

\section{WATER SECURITY STATUS AT THE WORLD SCALE}

From the analysis, the average water use unit, water productivity, grows with the GDP per capita growth though the agricultural water use in the high income group decreased due to the change of water use structure. In general, more water productivity induced better Water Security status. The water security index increased from the less income group countries to the lower middle income group and became stable in the upper middle and high income group due to the reduction of water disaster (which may reflect the data availability). The water productivity, measured by the income per capita and per water use unit, was assessed and compared with the water security index obtained and showed that more water productivity induced better water security status.

\section{THAILAND AND ASEAN}

The water security status of Thailand, compared with the world, Asia and the ASEAN regions were investigated with the ranking in each dimension as shown in Table 1. Within ASEAN 
Table 1 The average world, Asia and ASEAN water use status and the ranking of Thailand.

\begin{tabular}{|c|c|c|c|c|c|c|c|c|}
\hline \multirow{2}{*}{$\begin{array}{l}\text { Items } \\
\text { Basic water }\end{array}$} & \multirow{4}{*}{$\begin{array}{l}\text { Elements } \\
\text { 1. fresh water renewable }\left(\mathrm{m}^{3} / \text { capita }\right) \\
\text { 2. water supply }\left(\mathrm{m}^{3} / \text { capita }\right) \\
\text { 3. sanitation water }\left(\mathrm{m}^{3} / \text { capita }\right)\end{array}$} & \multirow{2}{*}{$\begin{array}{r}\begin{array}{l}\text { World } \\
\text { average }\end{array} \\
22,167\end{array}$} & \multicolumn{2}{|c|}{$\begin{array}{c}\text { Asia } \\
\text { ranking average }\end{array}$} & \multicolumn{2}{|c|}{$\begin{array}{r}\text { ASEAN } \\
\text { ranking average }\end{array}$} & ranking & Thailand \\
\hline & & & 79 & 10,854 & 15 & 19,205 & 8 & 6,382 \\
\hline & & 84 & 46 & 84 & 9 & 85 & 3 & 98 \\
\hline & & 67 & 15 & 70 & 6 & 71 & 2 & 96 \\
\hline \multirow{3}{*}{$\begin{array}{l}\text { Sufficient } \\
\text { water }\end{array}$} & 1. water use per capita (m³/capita) & 511 & 12 & 842 & 9 & 531 & 7 & 1,391 \\
\hline & 2. households (m³/capita) & 84 & 46 & 84 & 9 & 85 & 3 & 98 \\
\hline & 3. agricultural water $\left(\mathrm{m}^{3} /\right.$ capita $)$ & 354 & 159 & 712 & 7 & 424 & 1 & 1,322 \\
\hline \multirow{4}{*}{$\begin{array}{l}\text { Water for } \\
\text { development }\end{array}$} & 1. irrigation area $(\%)$ & 19 & 49 & 41 & 30 & 18 & 3 & 25 \\
\hline & 2. industrial water $\left(\mathrm{m}^{3} /\right.$ capita $)$ & 97 & 68 & 60 & 18 & 49 & 4 & 34 \\
\hline & 3. water for energy $(\%)$ & 31 & 89 & 20 & 23 & 14 & 6 & 4 \\
\hline & $\begin{array}{l}\text { 4. water for fresh water aquaculture } \\
\left(\mathrm{m}^{3} / \text { capita }\right)\end{array}$ & 346,734 & & $, 241,323$ & 4 & 582,458 & 2 & $1,385,801$ \\
\hline \multirow{2}{*}{$\begin{array}{l}\text { Water } \\
\text { disaster }\end{array}$} & 1. flood damage (US\$) & $3,543,108$ & & $, 670,092$ & 26 & $6,002,888$ & & $41,051,592$ \\
\hline & 2. drought damage (US\$) & $1,261,531$ & 22 & $, 896,770$ & 5 & 239,512 & 2 & 424,300 \\
\hline \multirow{3}{*}{$\begin{array}{l}\text { Water for } \\
\text { future }\end{array}$} & 1. population growth (\%) & 1.3 & 137 & 1.43 & 38 & 1.31 & 10 & 0.43 \\
\hline & 2. urban population growth $(\%)$ & 63 & 147 & 59 & 30 & 59 & 7 & 42 \\
\hline & 3. water footprint $\left(\mathrm{m}^{3} /\right.$ capita) & 1,338 & 7 & 1,304 & 2 & 1,697 & 2 & 2,223 \\
\hline \multirow{4}{*}{$\begin{array}{l}\text { Water } \\
\text { productivity }\end{array}$} & 1. GDP $\left(10^{6} \mathrm{US} \$\right)$ & 343,530 & 29 & 445,799 & 7 & 151,224 & 2 & 318,907 \\
\hline & 2. productivity(US\$ / m³ water) & 81 & 132 & 41.3 & 132 & 117.3 & 6 & 3.6 \\
\hline & $\begin{array}{l}\text { 3. agricultural productivity (US } \$ / \mathrm{m}^{3} \\
\text { water) }\end{array}$ & 392 & 124 & 33.8 & 18 & 162.5 & 7 & 0.32 \\
\hline & $\begin{array}{l}\text { 4. industrial productivity(US } \$ / \mathrm{m}^{3} \\
\text { water) }\end{array}$ & 169.1 & 63 & 69.5 & 8 & 121.6 & 4 & 51.2 \\
\hline
\end{tabular}

countries, the water use, water productivity and water security status of each country versus country GDP per capita were assessed comparatively and it showed that Thailand has the highest water use unit, moderate lower water productivity and a moderate water security ranking.

\section{CONCLUSIONS}

This study showed the status of water security of Thailand compared with the rest of the world. Thailand has strengths of clean water and sanitation water accessibility arising from the development investment in the past. However, the water use status regarding renewable freshwater and the agricultural sector, i.e. low efficiency, high water footprint, low productivity, seemed to be a weakness compared with other countries. There are potential demands for industrial water and water for energy, thus, the restructuring of the present water use structure is needed to cope with future water demand increase.

Acknowledgement This study is a supplementary part of the main research on Nan Basin Water Management Study funded by the Thailand Research Fund (TRF).

\section{REFERENCES}

Black, M. and King, J. (2009) The Atlas of Water. ISBN 978-0-520-25934-8, University of California Press.

World Bank (2014) http://data.worldbank.org/indicator/NY.GDP.MKTP.CD. 